\title{
Colocalization of Neurotensin Receptors and of the Neurotensin-Degrading Enzyme Endopeptidase 24-16 in Primary Cultures of Neurons
}

\author{
Joëlle Chabry, Frédéric Checler, Jean-Pierre Vincent, and Jean Mazella \\ Institut de Pharmacologie Moléculaire et Cellulaire du Centre National de la Recherche Scientifique, Sophia-Antipolis, \\ 06560 Valbonne, France
}

\begin{abstract}
This paper compares the localization of neurotensin receptors and of endopeptidase 24-16, a peptidase likely involved in the inactivation of neurotensin in primary cultures of neurons. Neurotensin binding sites were radiolabeled with ${ }^{25}$ |Tyr ${ }^{3}$-neurotensin, whereas endopeptidase 24-16 was stained by immunohistochemical techniques using a monospecific polyclonal antibody. Endopeptidase $24-16$ is present in 80$85 \%$ of the nondifferentiated neurons. The proportion of immunoreactive neurons decreased during maturation to reach 35-40\% after 4-8 d of culture. By contrast, neurotensin receptors were not detectable in nondifferentiated cells and appear during maturation. Specific ${ }^{125 \mid}{ }^{-T y{ }^{3}}{ }^{3}$ neurotensin labeling is maximal after $4 \mathrm{~d}$ of culture and is located on about $10 \%$ of differentiated neurons. Double-labeling experiments show that about $90 \%$ of cortical, hypothalamic, and mesencephalic neurons bearing the neurotensin receptor also contained endopeptidase 24-16, supporting the hypothesis that one of the functions of endopeptidase 24-16 is the physiological inactivation of neurotensin. However, the presence of endopeptidase 24-16 on numerous neurons that do not contain neurotensin receptors also suggests that the enzyme could be involved in the degradation and/or maturation of other neuropeptides.
\end{abstract}

The tridecapeptide neurotensin (NT) is distributed in discrete regions of the CNS of mammals (Carraway and Leeman, 1976; Cooper et al., 1981; Emson et al., 1982; Manberg et al., 1982), where this peptide likely plays an important role as a neurotransmitter or neuromodulator in ncuronal signaling (Gocdert, 1984; Nemeroff and Cain, 1985). Radioligand binding experiments on membrane preparations (Kitabgi et al., 1977; Uhl et al., 1977; Mazella et al., 1983; Sadoul et al., 1984a) and radioautographic studies on brain slices (Young and Kuhar, 1981; Quirion et al., 1982; Sadoul et al., 1984b; Hervé et al., 1986; Moyse et al., 1987) have detailed the biochemical properties and localization of specific high-affinity NT binding sites in the mammalian brain. In vitro studies on the mechanisms of NT inactivation in various membrane preparations or cell cultures

\footnotetext{
Received Mar. 8, 1990; revised June 22, 1990; accepted Aug. 17, 1990.

We wish to thank Valérie Dalmasso for expert secretarial assistance. This work was supported by the Institut National de la Santé et de la Recherche Médicale (CRE 886017), the Centre National de la Recherche Scientifique, and the Fondation pour la Recherche Médicale.

Correspondence should be addressed to Dr. Jean Mazella, IPMC CNRS, 660 Route des Lucioles, Sophia-Antipolis, 06560 Valbonne, France.

Copyright (C) 1990 Society for Neuroscience $0270-6474 / 90 / 123916-06 \$ 03.00 / 0$
}

(Dupont and Merand, 1978; McDermott et al., 1982; Checler et al., 1983, 1985) led to the detection of several peptidases that can be divided into 2 groups: (1) peptidases that are responsible for primary cleavages of the parent peptide, leading to degradation products totally devoid of biological activity (i.e., proline endopeptidase and endopeptidases 24-11, 24-15, and 24-16), and (2) enzymes that are involved in the secondary processing of NT degradation products that cannot be considered as inactivating peptidases, such as aminopeptidase(s), postproline dipeptidylaminopeptidase, and angiotensin-converting enzyme (Checler et al., 1988). We previously reported that primary cultures of differentiated neurons from mouse-embryo brains (Checler et al., 1986a) contain specific high-affinity NT receptors and the necessary enzymatic equipment to rapidly inactivate the peptide. Among the peptidases involved in the inactivation of the peptide, the recently purified endopeptidase 24-16 (Checler et al., 1986b) was particularly interesting with respect to the fact that this enzyme was previously shown to be the only peptidase present in all the tissues where NT receptors have been detected (Checler et al., 1988). This enzyme behaves as a good candidate for a physiological inactivation of NT and therefore was selected to examine whether such proteolytic activity could be associated with neuronal cells possessing NT binding sites that likely correspond to NT target cells. This was achieved by using an immunohistochemical approach with specific polyclonal antibodies developed against the enzyme and with radioactive labeling of receptors with ${ }^{125} \mathrm{I}-\mathrm{Tyr}^{3}-\mathrm{NT}$ in neurons from the cerebral cortex and other brain regions.

\section{Materials and Methods}

Cell cultures. Neuronal cells were prepared from the cerebral cortex, striatum, hypothalamus, and mesencephalic area of 14-d-old mouse embryos. Briefly, cells were mechanically dissociated with a pipet in a HAM-F1 2 medium (Gibco BRL) supplemented with $0.6 \%$ glucose, $10 \%$ fetal calf serum (Boehringer Mannheim), $100 \mathrm{U} / \mathrm{ml}$ penicillin, and 100 $\mu \mathrm{g} / \mathrm{ml}$ streptomycin. Dissociated cells were then plated at a density of $3 \cdot 10^{6}$ cells in $35-\mathrm{mm}$ (or $5 \cdot 10^{5}$ cells in $12-\mathrm{mm}$ ) plastic tissue-culture dishes precoated for $2-4 \mathrm{hr}$ with polylysine $(10 \mu \mathrm{g} / \mathrm{ml})$ and grown in a humidified atmosphere of $5 \% \mathrm{CO}_{2}, 95 \%$ air. Between days 3 and 4 of culture, cytosine arabinofuranoside $(40 \mu \mathrm{M})$ was added to prevent glialcell proliferation (Yavin and Yavin, 1974). Neurons were used for labeling of NT receptors and endopeptidase 24-16 throughout the differentiation process from day 0 (plating) to day 5-8.

We have previously demonstrated that glial cells as well as nondifferentiated neurons are devoid of NT binding sites (Checler et al., 1986a). Therefore, differentiated neurons can be characterized not only by their morphological shape (see Fig. 1), but also by their ability to bind ${ }^{125} \mathrm{I}$ $\mathrm{Tyr}^{3} \mathrm{NT}$.

Neurotensin degradation. Tritiated NT $\left(10^{5} \mathrm{cpm}, 40 \mathrm{Ci} / \mathrm{mmol}\right)$ was 

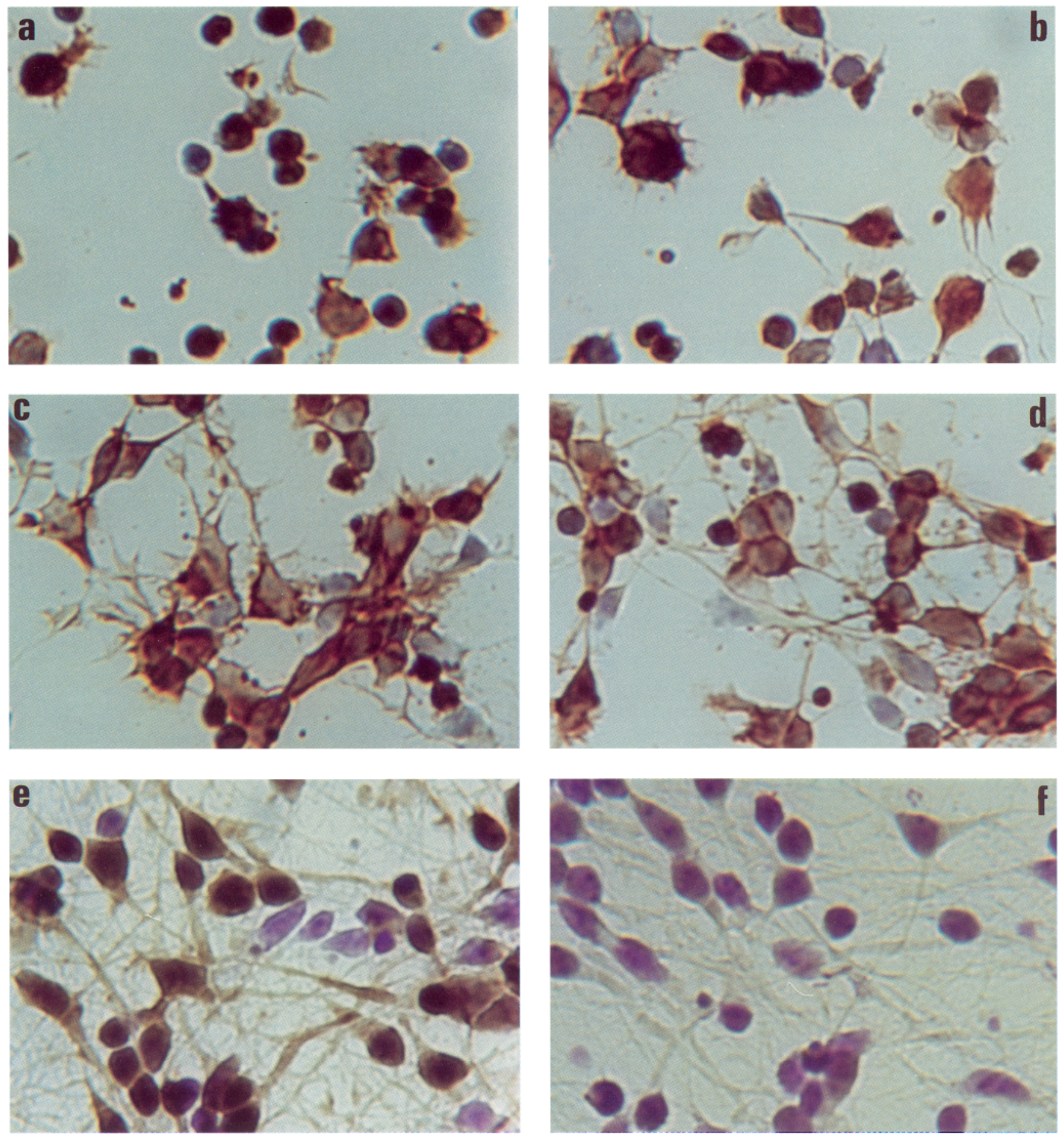

Figure 1. Labeling of endopeptidase 24-16 during differentiation of cortical neurons. Neurons obtained at different maturation states were fixed and cryoprotected as described in Materials and Methods, then incubated overnight at $4^{\circ} \mathrm{C}$ with immune $(a-e)$ or preimmune $(f)$ rabbit IgG fractions. After exposure with goat anti-rabbit IgG coupled to peroxidase, positive cells were revealed with DAB (brown cells). Nonreactive cells were further stained with cresyl violet (blue cells). Differentiation times were $a, 3 \mathrm{hr} ; b, 8 \mathrm{hr} ; c, 15 \mathrm{hr} ; d, 24 \mathrm{hr} ; e$ and $f, 48 \mathrm{hr}$. Magnification, $200 \times$.

incubated at $37^{\circ} \mathrm{C}$ with cortical neurons $\left(5 \cdot 10^{5}\right.$ cells/well) after $1 \mathrm{hr}$ (nondifferentiated) or $4 \mathrm{~d}$ (differentiated) of plating, alone or in the presence of various mixtures of inhibitors. The reaction was stopped after different times by acidification, and tritiated products were analyzed by high-pressure liquid chromatography (HPLC) as initially described (Checler et al., 1986a).

Neurotensin-receptor labeling. NT binding to attached neuronal cells was carried out at $37^{\circ} \mathrm{C}$ with $0.1 \mathrm{nM}^{125} \mathrm{I}-\mathrm{Tyr}^{3}-\mathrm{NT}(2000 \mathrm{Ci} / \mathrm{mmol}$; for details on iodination and purification, see Sadoul et al., 1984a) for 60 min in an Earl-HEPES-Tris buffer ( $\mathrm{pH}, 7.5$ ), supplemented with $0.01 \%$ glucose and $0.2 \%$ bovine serum albumin (standard conditions). Peptide degradation was prevented by addition of $1 \mathrm{~mm} o$-phenanthroline and $0.1 \mu \mathrm{M} Z$ Z-pro-prolinal (N-benzyloxycarbonyl-prolyl-prolinal) (Checler et al., 1986a). Nonspecific binding was determined in the presence of $1 \mu \mathrm{M}$ unlabeled NT and represented, in all cases, less than $2 \%$ of the total binding. At the end of incubations, cells were washed twice with 
Table 1. Degradation of neurotensin by differentiated and nondifferentiated neurons in culture

\begin{tabular}{|c|c|c|c|c|}
\hline \multirow[b]{2}{*}{$\begin{array}{l}\text { Peptide bond } \\
\text { cleaved }\end{array}$} & \multirow[b]{2}{*}{$\begin{array}{l}\text { Product } \\
\text { generated }\end{array}$} & \multirow[b]{2}{*}{ Enzyme responsible (identification) } & \multicolumn{2}{|c|}{ Initial rate of cleavage $\left(\mathrm{fmol} / \mathrm{min} / 10^{6}\right.$ cells) } \\
\hline & & & $\begin{array}{l}\text { Differentiated } \\
\text { neurons }\end{array}$ & $\begin{array}{l}\text { Nondifferentiated } \\
\text { neurons }\end{array}$ \\
\hline Pro $^{7}-\mathrm{Arg}^{8}$ & $\mathrm{NT}(1-7)$ & $\begin{array}{l}\text { Proline endopeptidase } \\
\text { (inhibited by } 0.1 \mu \mathrm{M} Z \text {-pro-prolinal) }\end{array}$ & $27.4 \pm 2.3$ & $24.8 \pm 2.7$ \\
\hline $\operatorname{Arg}^{8}-\operatorname{Arg}^{9}$ & NT(1-8) & $\begin{array}{l}\text { Endopeptidase } 24-15 \\
\text { (inhibited by } 2.5 \mu \mathrm{M} \text { CPE-Ala-Ala-Phe-pAB) }\end{array}$ & $27.0 \pm 3.1$ & $22.9 \pm 2.4$ \\
\hline Pro $^{10}-\mathrm{Tyr}^{11}$ & NT(1-10) & $\begin{array}{l}\text { Proline endopeptidase } \\
\text { (inhibited by } Z \text {-pro-prolinal) } \\
\text { with endopeptidase } 24-16 \\
\text { (insensitive to a mixture of inhibitors) }^{b}\end{array}$ & $30.4 \pm 3.7$ & $29.3 \pm 2.8$ \\
\hline
\end{tabular}

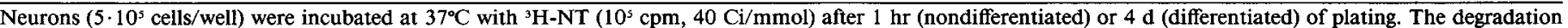

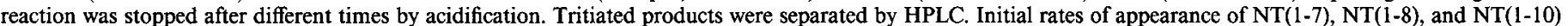
are expressed in fmol peptide generated per min per $10^{6}$ plated cells. Values are the mean \pm SEM of 3 experiments.

a Differences observed between differentiated and nondifferentiated neurons were not statistically significant.

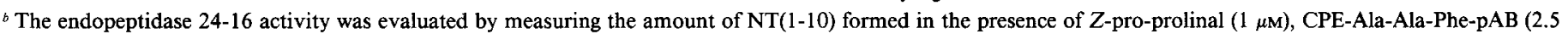
$\mu \mathrm{M})$, bestatin $(10 \mu \mathrm{M})$, thiorphan $(1 \mu \mathrm{M})$, captopril $(1 \mu \mathrm{M})$.

$1 \mathrm{ml}$ incubation buffer, then immediately fixed by immersion in $3.5 \%$ glutaraldehyde in phosphate buffer for $10 \mathrm{~min}$ at $4^{\circ} \mathrm{C}$. This procedure led to cross-linking of $60-70 \%$ of ${ }^{125} \mathrm{I}_{-} \mathrm{Tyr}^{3}$-NT bound to neurons.

Endopeptidase 24-16 labeling. The glutaraldehyde-fixed cells were processed for detection of endopeptidase 24-16 using the IgG-purified fraction of a monospecific rabbit polyclonal antiserum prepared from the rat-brain purified enzyme (Checler et al., 1989). Briefly, cells were cryoprotected by incubation for $30 \mathrm{~min}$ in a phosphate buffer ( 1 vol 0.2 M $\mathrm{NaH}_{2} \mathrm{PO}_{4}, 5$ vol $0.2 \mathrm{M} \mathrm{K}_{2} \mathrm{HPO}_{4}$ ) containing $30 \%$ sucrose, then frozen for $15 \mathrm{sec}$ at $-40^{\circ} \mathrm{C}$ in methyl-2-butane. In order to block nonspecific sites for IgG, neurons were rinsed with a $50-\mathrm{mm}$ Tris- $\mathrm{HCl}$ buffer $(\mathrm{pH}$, 7.5) containing $140 \mathrm{~mm} \mathrm{NaCl}$ (Tris- $\mathrm{NaCl}$ buffer) and incubated for 30 min in this Tris-NaCl buffer in the presence of $3 \%$ skim milk and $0.2 \%$ Triton X-100. Fixed cells were rinsed twice with $1 \%$ skim milk in Tris$\mathrm{NaCl}$ buffer and exposed in the same buffer overnight at $4^{\circ} \mathrm{C}$ to a 1:300 dilution of the immune or preimmune $\mathrm{IgG}$ fractions. Finally, dishes were exposed for $90 \mathrm{~min}$ to a 1:200 dilution of goat anti-rabbit IgG coupled to peroxidase according to the manufacturer's recommendations (Pharmacia). Cells were rinsed as above and the IgG-antigen complexes were revealed with diaminobenzidine (DAB). After dehydration with graded ethanols, neurons that were only exposed to the antibodies against endopeptidase 24-16 were stained with cresyl violet. Neurons processed for both peptidase and NT-receptor detections were directly radioautographed, after cutting off the sides of the Petri dishes, by dipping in Kodak NTB-3 emulsion diluted 1:1. Radioautograms were developed with $\mathrm{D}-19\left(2 \mathrm{~min}, 17^{\circ} \mathrm{C}\right)$ after $1-4$ weeks of exposure. Cells were then stained with cresyl violet, coverslipped with glycerol, and examined with a Leitz Aristoplan microscope.

Statistical analyses were carried out according to the Student's $t$ test.

\section{Results}

Identification of peptidases involved in neurotensin degradation by nondifferentiated neurons

Primary cultures of differentiated neurons contain both NT receptors of high affinity and proteolytic activities that can efficiently degrade NT (Checler et al., 1986a). Because NT binding sites were not detectable in nondifferentiated neurons, it was important to assess whether the same NT-degrading activities were present in neuronal cultures before and after in vitro differentiation. Table 1 indicates that, whatever the time of maturation in vitro, incubation of NT with neuronal cells leads to primary cleavages at the $7-8,8-9$, and $10-11$ peptide bonds of the NT molecule. Proline endopeptidase is responsible for the cleavage of the $\mathrm{Pro}^{7}-\mathrm{Arg}^{8}$ bond and contributes to the hydrolysis of the Pro ${ }^{10}-\mathrm{Tyr}^{11}$ bond, because productions of NT(1-7) and
NT(1-10) can be entirely and partially prevented, respectively, by the specific proline endopeptidase inhibitor $Z$-pro-prolinal (Wilk and Orlowski, 1983). The remaining formation of NT(110) can be likely attributed to the recently purified endopeptidase 24-16 (Checler et al., 1986b). Indeed, this fraction of NT(110) appeared resistant to a mixture of inhibitors developed against all the previously purified NT(1-10)- and NT(1113)-generating activities, namely, endopeptidase 24-11 (blocked by thiorphan) and proline endopeptidase (inhibited by $Z$-proprolinal). Furthermore, Western blot analysis demonstrated the presence of endopeptidase 24-16 in homogenates of differentiated neurons and was corroborated by the immunohistochemical approach described in the present study. Finally, cleavage of the $\mathrm{Arg}^{8}-\mathrm{Arg}^{9}$ bond is due to endopeptidase 24-15, because formation of NT(1-8) is inhibited by CPE-Ala-Ala-Phe-pAB(N[1(R,S)-carboxy-2-phenylethyl]-alanyl-alanyl-phenylalanyl-paminobenzoate), a specific inhibitor of endopeptidase 24-15 (Chu and Orlowski, 1984). Neither thiorphan (Roques et al., 1980) nor captopril (Ondetti et al., 1977) affect the profile of NT degradation, indicating that endopeptidase 24-11 and angiotensinconverting enzyme are not involved in the hydrolysis of NT by nondifferentiated neurons.

Table 1 also shows that the initial rates of appearance of products generated by primary cleavages are virtually identical for differentiated and nondifferentiated neurons. In addition, the same secondary processing of products generated by primary cleavages that have been characterized with differentiated neurons (Checler et al., 1986a) can also be observed immediately after plating (results not shown). Finally, the half-life of NT in the presence of cultured neurons is about $15 \mathrm{~min}$, whatever the degree of maturation. Taken together, these results clearly show that the set of proteolytic activities involved in NT inactivation remains qualitatively or quantitatively very similar during the course of the in vitro differentiation process of cultured neurons. Among the 3 peptidases described in Table 1, endopeptidase 24-16 was chosen as a marker of NT metabolism because this enzyme is present in all tissues, cells, or membrane preparations where NT receptors have been detected and therefore behaves as a putative candidate for a physiological inactivation of the peptide (Checler et al., 1988) 
Labeling of endopeptidase 24-16 during the differentiation of neurons

In the presence of polylysine, cortical neurons are rapidly attached on the culture dishes. Therefore, growth cones can be observed as early as $1-3 \mathrm{hr}$ after seeding (Fig. 1a). These initial processes grow rapidly in length and in the number of small neurites until $24 \mathrm{hr}$ of plating (Fig. $1 a-d$ ), then form a continuous network between 1 and $4 \mathrm{~d}$ in vitro (Fig. $1 e, f$ ). Between 1 and $15 \mathrm{hr}$ of in vitro differentiation, $80-85 \%$ of cells are positive to anti-endopeptidase 24-16 antibodies (Fig. $1 a-c$, brown cells). It is interesting to note that, until 5-8 hr after seeding, almost all neurons showing extended neurites contain the metallopeptidase (Fig. $1 a, b$ ). Nonpositive cells begin to differentiate later (Fig. 1c). The amount of immunopositive neuronal cells decreases from $80 \%$ at $15 \mathrm{hr}$ of seeding to $35-40 \%$ at the advanced differentiated state of $4 \mathrm{~d}$ (Fig. 1a-e). This proportion does not change until $8 \mathrm{~d}$ (Fig. 2). Note that the enzyme labeling of cortical differentiated neuronal cells appears both in perikarya and in extended processes. When cells are incubated with the preimmune serum in identical conditions of dilution (Fig. 1f), no labeling appears with $\mathrm{DAB}$, demonstrating the absolute specificity of antibodies as previously described (Checler et al., 1989).

Figure 2 illustrates the various proportions of cortical neurons containing endopeptidase 24-16 during differentiation in vitro. Taking into account the plateau value of $35 \%$ at maturation, the half-life of the endopeptidase in neurons during differentiation is about $35 \mathrm{hr}$.

\section{Double labeling of neurotensin receptors and endopeptidase 24-16}

We have previously demonstrated that, in cortical neurons, NT receptors reached a maximal capacity after $4 \mathrm{~d}$ of culture without any change of affinity (Checler et al., 1986a). Therefore, in order to have sufficient radioactive labeling, all experiments of colocalization have been carried out after 4 or $5 \mathrm{~d}$ of seeding. In light microscopic radioautograms from cortical preparations (Fig. $3 a, b)$, one can observe a selective accumulation of silver grains (i.e., NT receptors) over a subpopulation of nerve cell bodies and neuronal processes of neurons that contain endopeptidase 24-16 (brown cells). The proportion of NT-receptor-labeled cells is estimated at approximately $10 \%$. Silver grains observed over fields between cell bodies are actually localized on fine processes that cannot be visualized on this figure. Preparations incubated in the presence of $1 \mu \mathrm{M}$ unlabeled NT (Fig. 3c) are totally devoid of silver grains. When several fields of vision are examined, some neurons totally negative to the enzyme antibodies show a labeling for NT receptors. The amount of this population of cells never exceeds $1.5 \%$.

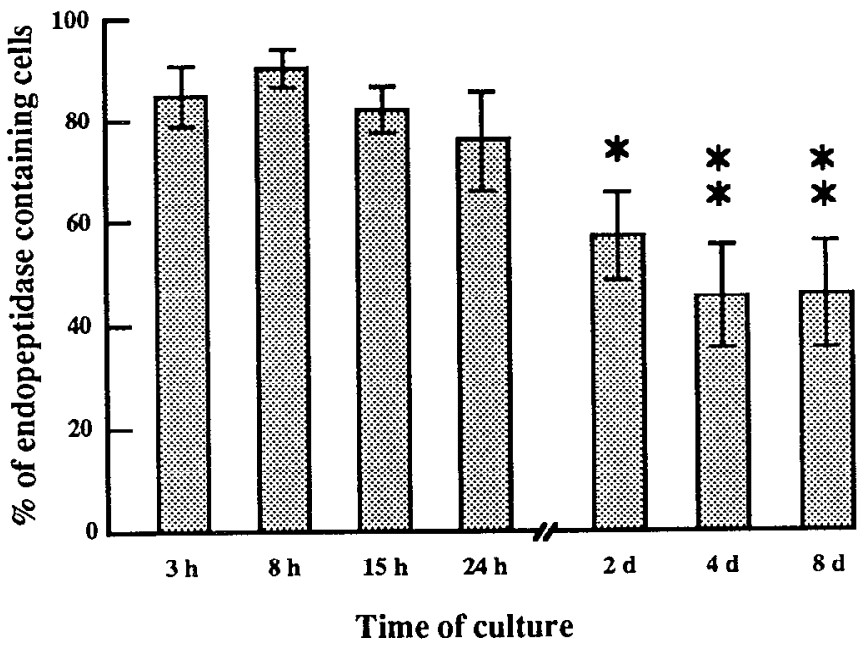

Figure 2. Proportion of cortical cells immunostained with anti-endopeptidase 24-16 antibodies during in vitro differentiation. Immunopositive cells detected as described in Materials and Methods at the indicated times of seeding were expressed as a percentage of the total counted cells. Each bar corresponds to the mean \pm SEM of 4-6 different determinations carried out in 3 different cultures. *, significantly different from the 3 -hr value $(p<0.01)$; ${ }^{* *}$, significantly different from the 3 -hr value $(p<0.005)$.

\section{Double labeling in different brain areas}

Table 2 summarizes the proportions of neuronal cells that contain endopeptidase 24-16 and NT receptors in different brain areas. As described above for the cortex, 35-40\% of in vitro differentiated neurons express the enzyme in the hypothalamus as well as in the mesencephalic area and striatum. By contrast, the density of NT-receptor-labeled cells seems to be greater in the cortex $(11 \%)$ than in other regions studied (about 6\%). It is important to note that, except for the mesencephalic area, 80 $90 \%$ of neurons containing NT receptors also contain endopeptidase 24-16.

\section{Discussion}

The present report demonstrates the colocalization of specific NT binding sites and endopeptidase 24-16, one of the enzymes responsible for the degradation of the peptide, in neurons originating from various brain areas. This evidence has been obtained using a double-labeling technique involving immunohistochemical staining of the enzyme and radioactive labeling of the receptor.

In contrast to NT receptors, peptidases involved in the inactivation of the neuropeptide are present in the mouse brain

Table 2. Distribution of endopeptidase 24-16 and NT binding sites in primary cultured neurons from various cerebral areas of mouse embryos.

\begin{tabular}{lllll} 
Brain area & $\begin{array}{l}\text { Endopeptidase 24-16- } \\
\text { positive cells (\%) }\end{array}$ & $\begin{array}{l}\text { 125I-Tyr }{ }^{3} \text {-NT } \\
\text { labeled cells (\%) }\end{array}$ & $\begin{array}{l}\text { Endopeptidase 24-16- } \\
\text { and }{ }^{125} \text { I-Tyr }{ }^{3} \text {-NT } \\
\text { labeled cells (\%) }\end{array}$ & $\begin{array}{l}\text { 125I-Tyr }{ }^{3}-N T \text { labeled cells } \\
\text { positive to } \\
\text { endopeptidase 24-16 (\%) }\end{array}$ \\
\hline Cortex & $38.8 \pm 2.9$ & $12.7 \pm 2.2$ & $11.2 \pm 1.6$ & $88.7 \pm 3.2$ \\
Hypothalamus & $32.5 \pm 5.2$ & $6.8 \pm 0.6$ & $6.1 \pm 0.8$ & $89.4 \pm 5.6$ \\
Mesencephalon & $35.6 \pm 7.8$ & $7.6 \pm 1.0$ & $5.0 \pm 0.9$ & $65.7 \pm 5.3^{*}$ \\
Striatum & $31.0 \pm 4.1$ & $7.1 \pm 1.0$ & $6.0 \pm 1.4$ & $83.4 \pm 7.6$
\end{tabular}

Neurons cultured from different brain areas were used after $4 \mathrm{~d}$ differentiation for the detection of endopeptidase 24-16 by using specific polyclonal antibodies and detection of NT binding sites with ${ }^{125} \mathrm{I}-\mathrm{Tyr}^{3}$-NT (see Materials and Methods). Values are means \pm SEM from 3 different experiments.

*, Significantly different from the cortex $(p<0.005)$, hypothalamus $(p<0.01)$, and striatum $(p<0.05)$. 

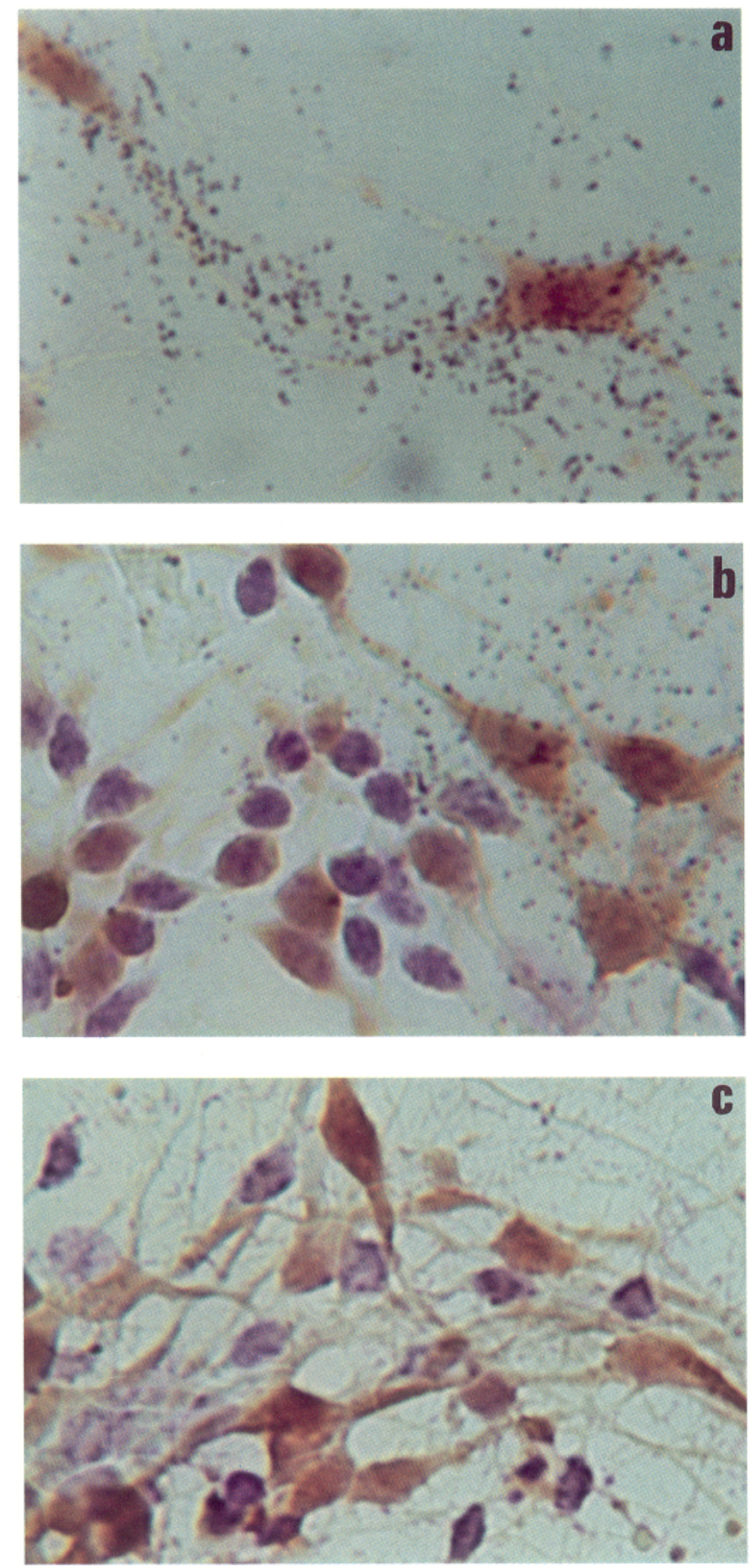

Figure 3. Immunochemical staining of endopeptidase 24-16 and radiolabeling of NT receptors on cortical neurons. Differentiated neuronal cells $(5 \mathrm{~d})$ were incubated with $0.1 \mathrm{nM}^{125} \mathrm{I}_{-} \mathrm{Tyr}^{3}-\mathrm{NT}$ in the absence $(a$, $b)$ or in the presence $(c)$ of $1 \mu \mathrm{M}$ unlabeled NT. After incubation, cells were rinsed, fixed in $3.5 \%$ glutaraldehyde, then processed for immunochemical detection of endopeptidase $24-16$ as described in Materials and Methods. The sides of the Petri dishes were cut off, and neurons were radioautographed by dipping in Kodak NTB-3 emulsion and revealed after 1 week of exposure. The radiolabeling of NT receptors (dark grains in $a, b$ ) was essentially localized on neurons and neurites bearing endopeptidase 24-16 (brown cells) and selectively protected by unlabeled NT (c). Magnification, $200 \times$. at the embryonic state, because they are able to degrade NT added to neurons as early as $1 \mathrm{hr}$ after seeding (Table 1). As initially described (Checler et al., 1986a), NT binding sites are not detectable in nondifferentiated cortical neurons and appear only during the in vitro differentiation procedure to reach a maximal value after $4 \mathrm{~d}$ of plating on polylysine-coated dishes. The presence of endopeptidase 24-16 in immature neurons has first been suggested by the fact that, as in differentiated neurons, part of the cleavage at $\mathrm{Pro}^{10}-\mathrm{Tyr}^{11}$ leading to NT(1-10) formation is insensitive to a mixture of inhibitors developed against all the previously purified NT(1-10)- and NT(11-13)-generating activities and by immunochemical detection of the peptidase in homogenates of differentiated neurons prepared from primary cultures of cerebral hemispheres of mouse embryos (Checler et al., 1989). The presence of the peptidase is clearly demonstrated by immunohistochemistry using monospecific polyclonal antibodies prepared from the rat brain purified enzyme (Checler et al. 1989). Interestingly, the proportion of immunopositive neuronal cells varies all along the differentiation process. Indeed, from plating and during the first $12 \mathrm{hr}, 80-85 \%$ of cortical neuronal cells are immunologically stained and thus' contain the metallopeptidase. The amount of these labeled cells decreases during maturation and reaches a value of about $35-40 \%$ between 4 and $8 \mathrm{~d}$, a value that may represent the amount of peptidasecontaining neurons in the cortical area of the intact brain.

The metalloendopeptidase 24-16 has been described as an enzyme present in both the cytosoluble and the membranebound fractions of differentiated cultured neurons from mouseembryo cerebral cortex (Checler et al., 1989). Accordingly, the immunohistochemical labeling is detected all over cell bodies and nerve processes of neurons because light microscopy cannot discriminate between the cytosol and the membranes (Fig. 1). The immune serum against the peptidase is specific to a 70$\mathrm{kDa}$ protein present in the murine brain (Checler et al., 1989). The specificity of IgG fractions to immunostain neurons containing this $70-\mathrm{kDa}$ protein has been demonstrated elsewhere and is confirmed here by use of the preimmune serum that shows no labeling of either cell bodies or neurites (Fig. $1 f$ ).

On differentiated cortical neurons, the labeling of NT receptors is observed on nerve cell bodies and large processes, and also on small neurites (Fig. $3 a, b$ ). This specific labeling appears over a subpopulation of cells estimated to $11 \%$, taking into account the difficulty of assigning silver grains to a determined cell when several nerve processes intersect. The important point to stress (Table 2) is that NT receptors are almost always localized on neurons containing the metallopeptidase (80-90\%), supporting the hypothesis that the enzyme must be present on NT target cells in order to terminate the peptide action. This colocalization not only appears on cell bodies, but also on extended neurites (Fig. 3a,b). However, as detailed in Table 2, the amount of NT-receptor-positive neurons represents about 35\% of the endopeptidase-containing cells, suggesting a possible role of the enzyme in other degradation or maturation processings. This hypothesis is in agreement with a previous study (Barelli et al., 1988) demonstrating the ability of the purified endopeptidase 24-16 to degrade other peptides such as bradykinin, dynorphin 1-8, and angiotensins I and II with potencies identical with that found for NT. Moreover, the presence of the peptidase in nondifferentiated neurons while NT receptors are not yet expressed could be explained by a possible involvement of this and other peptidases in the differentiation program or maturation processes. 
Only $10 \%$ of cells showing a labeling with ${ }^{125} \mathrm{I}_{-} \mathrm{Tyr}^{3}-\mathrm{NT}$ are devoid of endopeptidase 24-16 (Table 2). The most probable explanation is that, in the absence of endopeptidase 24-16, the process of NT degradation is carried out by other enzymes present in cortical neurons. The low proportion of this kind of cell indicates that endopeptidase 24-16, though not absolutely necessary, is most often involved in NT degradation.

Finally, we have also attempted to examine the distribution of NT receptors and endopeptidase 24-16 in neuronal cultures from the midbrain, hypothalamus, and striatum (Table 2). No important difference appears concerning the detection of the peptidase because similar proportions of stained cells (about $40 \%$ ) were obtained, whatever the brain area analyzed. This result could explain the preliminary experiments demonstrating a rather homogeneous label of the enzyme obtained after immunohistochemical approaches on intact brain slices, particularly if one assumes that the proportion of labeled cells remains constant in other brain areas. In comparison to the cerebral cortex, the amount of neurons labeled with ${ }^{125} \mathrm{I}-\mathrm{Tyr}^{3}-\mathrm{NT}$ is less important in the hypothalamus, midbrain, and striatum (Table 2). The presence of NT binding sites in these regions and the higher proportion of receptors in cortical neurons confirm previous findings obtained in the course of an autoradiographic study of brain NT-receptor ontogeny (Palacios et al., 1988), in which an intense labeling was observed in the cortex of newborn rats.

The localization of NT receptors on endopeptidase 24-16positive cells remains in identical proportion in cortical, hypothalamic, and striatal neurons (Table 2), except in the midbrain, where this proportion is only $65 \%$.

In conclusion, this study demonstrates that in cultured ncurons from mouse-embryo brains, NT receptors are colocalized with the NT-degrading enzyme endopeptidase 24-16. Further studies are required to identify the neurotransmitter content of neurons possessing NT receptors and/or endopeptidase 24-16, for example, by using double immunostaining and radioactive labeling. Such experiments should be important to study the physiological action and inactivation of endogenous NT.

\section{References}

Barelli H, Girard F, St Pierre S, Kitabgi P, Vincent JP, Checler F (1988) Further characterization of a neurotensin-degrading neutral metalloendopeptidase from rat brain. Neurochem Int 12:351-359.

Carraway RE, Leeman SE (1976) Characterization of radioimmunoassayable neurotensin in the rat. Its differential distribution in the central nervous system, small intestine and stomach. J Biol Chem 251:7045-7052.

Checler F, Vincent JP, Kitabgi P (1983) Degradation of neurotensin by rat brain synaptic membranes. Involvement of a thermolysin-like metallocndopeptidase (enkephalinase), angiotensin-converting enzyme and other unidentified peptidases. J Neurochem 41:375-384.

Checler F, Vincent JP, Kitabgi P (1985) Inactivation of neurotensin by rat brain synaptic membranes partly occurs through cleavage at the $\mathrm{Arg}^{8}-\mathrm{Arg}^{9}$ peptide bond by a metalloendopeptidase. J Neurochem 45:1509-1513.

Checler F, Mazella J, Kitabgi P, Vincent JP (1986a) High affinity receptor sites and rapid proteolytic inactivation of neurotensin in primary cultured neurons. J Neurochem 47:1742-1748.

Checler F, Vincent JP, Kitabgi P (1986b) Purification and characterization of a novel neurotensin-degrading peptidase from rat brain synaptic membranes. J Biol Chem 261:11274-11281.

Checler F, Barelli H, Kitabgi P, Vincent JP (1988) Neurotensin metabolism in various tissues of central and peripheral origins: ubiquitous involvement of a novel neurotensin degrading metalloendopeptidase. Biochimie 70:75-82.
Checler F, Barelli H, Vincent IP (1989) Tissue distribution of a novel neurotensin-degrading metallopeptidase. An immunological approach using monospecific polyclonal antibodies. Biochem J 257: 549-554.

Chu TG, Orlowski M (1984) Active site directed $N$-carboxy-methyl peptide inhibitors of a soluble metallopeptidase from rat brain. Biochemistry 23:3598-3603.

Cooper PE, Fernstrom MH, Rorstad OP, Leeman SE, Martin JB (1981) The regional distribution of somatostatin, substance $P$ and neurotensin in human brain. Brain Res 218:219-232.

Dupont A, Merand Y (1978) Enzymatic inactivation of neurotensin by hypothalamic and brain extracts of the rat. Life Sci 22:1623-1630.

Emson PC, Goedert M, Horsfield P, Rioux F, Saint-Pierre S (1982) The regional distribution and chromatographic characterization of neurotensin-like immunoreactivity in the central nervous system. $\mathrm{J}$ Neurochem 38:992-1000.

Goedert M (1984) Neurotensin-a status report. Trends Neurosci 7: 3-5.

Hervé D, Tassin JP, Studler JM, Dana C, Kitabgi P, Vincent JP, Glowinski J, Rostène W (1986) Dopaminergic control of ${ }^{125}$ I-labeled neurotensin binding site density in corticolimbic structures of rat brain. Proc Natl Acad Sci USA 83:6203-6207.

Kitabgi P, Carraway RE, Van Rietschoten J, Granier C, Morgat JL, Menez A, Leeman S, Freychet P (1977) Neurotensin: specific binding to synaptic membranes from rat brain. Proc Natl Acad Sci USA 74:1846-1850.

Manberg PJ, Youngblood WW, Nemeroff CB (1982) Regional distribution of neurotensin in human brain. J Neurochem 38:1777-1780.

Mazella J, Poustis C, Labbé C, Checler F, Kitabgi P, Granier C, Van Rietschoten J, Vincent JP (1983) Monoiodo-Trp ${ }^{11}$-neurotensin, a highly radioactive ligand of neurotensin receptors. Preparation, biological activity and binding properties to rat brain synaptic membranes. J Biol Chem 258:3476-3481.

McDermott JR, Smith AI, Edwardson JA, Griffiths EC (1982) Mechanism of neurotensin degradation by rat brain peptidase. Reg Peptides 3:397-404.

Moyse E, Rostène W, Vial M, Leonard K, Mazella J, Kitabgi P, Vincent JP, Beaudet A (1987) Regional distribution of neurotensin binding sites in rat brain: a film and light microscopic radioautographic study using monoiodo ${ }^{125} \mathrm{I}_{-\mathrm{Tyr}^{3}}$-neurotensin. Neuroscience 22:527-536.

Nemeroff CB, Cain ST (1985) Neurotensin-dopamine interactions in the CNS. Trends Pharmacol Sci 6:201-205.

Ondetti MA, Rubin B, Cushman DW (1977) Design of specific inhibitors of angiotensin-converting enzyme: new class of orally antihypertensive agents. Science 196:441-444.

Palacios JM, Pazos A, Diehl MM, Schlumpf M, Lichtensteiger W (1988) Ontogeny of brain neurotensin receptors studied by autoradiography. Neuroscience 25:307-317.

Quirion R, Gaudreau P, Saint-Pierre S, Rioux F, Pert CB (1982) Autoradiographic distribution of ${ }^{3} \mathrm{H}$-neurotensin receptors in rat brain: visualization by tritium-sensitive film. Peptides 3:757-763.

Roques BP, Fournie-Zaluski MC, Soroca E, Lecomte JH, Malfroy B, Llorens C, Schwartz JC 1980) The enkephalinase inhibitor thiorphan shows antinociceptive activity in mice. Nature 288:286-288.

Sadoul JL, Mazella J, Amar S, Kitabgi P, Vincent JP (1984a) Preparation of neurotensin selectively iodinated on the tyrosine 3 residue. Biological activity and binding properties on mammalian neurotensin receptors. Biochem Biophys Res Commun 120:812-819.

Sadoul JL, Checler F, Kitabgi F, Rostène W, Javoy-Agid F, Vincent JP (1984b) Loss of high affinity neurotensin receptors in substantia nigra from parkinsonian subjects. Biochem Biophys Res Commun 125: 395-404.

Uhl GR, Bennett JP Jr, Snyder SH (1977) Ncurotensin: a central nervous system peptide. Apparent receptor binding in brain membranes. Brain Res 130:299-313.

Wilk S, Orlowski M (1983) Inhibition of a rabbit brain prolyl endopeptidase by $N$-benzyloxycarbonyl-prolyl-prolinal, a transition state aldehyde inhibitor. J Neurochem 41:69-75.

Yavin E, Yavin Z (1974) Attachment and culture of dissociated cells from rat embryos cerebral hemispheres on polylysine-coated surface. J Cell Biol 62:540-546.

Young WS III, Kuhar MJ (1981) Neurotensin receptor localization by light microscopic autoradiography in rat brain. Brain Res 206 : 273-285. 